\title{
Evaluation of Expression CXCL8 Chemokine and Its Relationship With Oocyte Maturation and Embryo Quality in Intracytoplasmic Sperm Injection Method
}

\section{Maryam Jenabi}

Parand Branch, Islamic Azad University

Parvin Khodarahmi ( $\square$ khodarahmiparvin@yahoo.com )

Parand Branch, Islamic Azad University https://orcid.org/0000-0001-6252-4254

Farzaneh Tafvizi

Parand Branch, Islamic Azad University

Saeed Zaker Bostanabad

Parand Branch, Islamic Azad University

\section{Research Article}

Keywords: CXCL8, Follicular fluid, Cumulus cells, Oocyte maturation, ICSI

Posted Date: January 28th, 2022

DOI: https://doi.org/10.21203/rs.3.rs-1290772/v1

License: (c) (i) This work is licensed under a Creative Commons Attribution 4.0 International License. Read Full License 


\section{Abstract}

Background

The present study aimed to evaluate the expression of the chemokine CXCL8 in both mRNA and protein levels in the serum, follicular fluid (FF), and cumulus cells (CCs) and its relationship with oocyte maturation and embryo quality in women undergoing intracytoplasmic sperm injection (ICSI).

\section{Methods}

A total of 87 women who underwent an ICSI cycle were evaluated in two groups, including the test group (female factor infertility) and the control group (fertile). In the serum, FF, and CCs, the protein and mRNA expression of CXCL8 were measured using immunosorbent assay and Real-Time PCR, respectively. The quality and quantity of the oocytes and embryos were assessed, and relationship of protein and MRNA CXCL8 was evaluated with oocyte maturation and embryo quality.

Results

The level of protein and mRNA of CXCL8 was significantly higher in the serum, FF, and CCs in the test group than in the control group. In the test group, the expression of mRNA and protein of CXCL8 had a significant increase in FF and CCs compared to serum; also, there was a CXCL8 protein significant increase in FF compared to CCs. The count of oocytes obtained, MII oocytes, and the percentage of oocyte maturity significantly decreased in the test group. The expression of CXCL8 was inversely related to oocyte maturation, but no relationship was observed with embryo quality.

Conclusion

The elevated concentrations of CXCL8 in the serum and FF seem to be a predictor as a potential non-invasive biomarker for the oocyte maturation outcome in women with female factor infertility.

\section{Introduction}

Infertility is a common disease that affects marital relationships, mental health, and the quality of married life. Assisted reproductive technology (ART), including in-vitro fertilization (IVF) and intracytoplasmic sperm injection (ICSI), have taken essential steps in treating infertility couples. The immune system is a well-known factor affecting the reproduction system's balance [1], so that imbalance of this system, such as inflammatory and immunological disorders, causes infertility, especially infertility with female factor[2]. The studies indicate that the chemokines as a family of immune system's cytokines have an important role in the reproduction system. They are small polypeptides that regulate the uptake and traffic of leukocytes to inflammatory sites[3]. The chemokines, as the secretory products of the immune system, are involved in the emergence and development of many factors related to fertility in women, including endometriosis, polycystic ovary syndrome, primary ovarian insufficiency, folliculogenesis, embryo quality, implantation, and pregnancy[4-7].

Chemokine CXCL8 or interleukin 8 (IL-8) is an important chemokine in the reproductive process that belongs to the alpha chemokine's family. This chemokine is a chemical adsorbent of white blood cells, neutrophils, and lymphocytes and has many pro-inflammatory effects[8]. Chemokine CXCL8 is present in ovarian cells and follicles before ovulation and involved in the natural processes of folliculogenesis and ovulation[9, 10]. The 
folliculogenesis phenomenon is an inflammatory process resulting from the interaction of ovarian immune cells with leukocytes and inflammatory mediators such as chemokines[11]. The CXCL8 regulates follicle maturation through activation and chemotaxis of granulocytes and leukocytes[12-14]. It has been proven that chemokine CXCL8 plays a critical role in developing follicles as an essential part of folliculogenesis in ART cycles[15, 16]. On the other hand, this chemokine is involved in cleavage, development up to the blastocyst stage, and embryo implantation; it is also secreted in the embryo, and along with chemokines derived from the uterus, it causes more immune cells to accumulate around the embryo and helping to improve implantation[17].

The studies were indicated that the cytokines and chemokines are present in the follicular fluid as a factor influencing oocyte quality and ICSI results[15]. The follicular fluid, the medium around the oocyte, and cumulus oophorus cells affect the growth ability and oocyte maturity $[8,9,18]$. It has been proven that the changes in follicular fluid content can be considered predictors of oocyte and embryo quality[19-22]. The quality of oocyte maturation is a determinant factor of the results of ART in subfertile women [23].

According to the reactions between the endocrine system and chemokines in the ovary and the effect of chemokine changes on the folliculogenesis and the results of ART, the present study aimed to investigate the expression of Chemokine CXCL8 protein and mRNA in the serum, follicular fluid, and cumulus cells and its relationship with oocyte maturation and embryo quality in women undergoing ICSI.

\section{Material \& Method}

\subsection{Blood biochemical assay}

The present test-control study was conducted on 200 Infertile couples undergoing ICSI treatment at Academic Center for Education, Culture and Research (ACECR), Infertility Center, Arak, Iran. The women with an average age of 20 to 35 years and a body mass index of less than $27 \mathrm{~kg} / \mathrm{m} 2$ were selected for the study. The women were excluded from the study if they had fertility supplements, mixed factors infertility, closed fallopian tubes, inflammation or infectious conditions, autoimmune diseases, cardiovascular problems, diabetes, and smoking addiction. Endocrine hormones, including Follicle Stimulating Hormone (FSH), Luteinizing Hormone (LH), Thyroidstimulating Hormone (TSH), Prolactin (PRL), and Anti Mullerian Hormone (AMH) were measured using enzymatic kits (Pishtazteb Kit, Iran) according to the manufacturer's instructions. The women with normal test results were selected in this study. Finally, 54 subfertile women with female factor infertility were selected as the test group, and 33 fertile women with male factor infertility were selected as the control group. Semen samples were analyzed according to the World Health Organization guidelines[24]. Written consent forms were signed by the patients with the approval of the Ethics Committee in Human Research with the code IR.IAU.VARAMIN.REC.1399.035.

\subsection{Samples collection of serum, follicular fluid, and cumulus cells}

Women underwent controlled ovarian hyperstimulation via gonadotropin-releasing hormone (GnRH) protocols. Either agonist long or antagonist were selected by each physician and were individualized based on the results of the patient's ovarian reserve. In some patients, the controlled ovarian stimulation was initiated with agonist long recombinant follicle stimulation hormone (Gonal-F; Merk Serono, Germany) at the mid-luteal phase of the previous cycle and continued to the day of hCG injection in some patients. The other patients were administered antagonist drugs daily (Cetrotide; Merk Serono, Germany) at the mid-follicular phase until the size of follicles reached $12 \mathrm{~mm}$ 
at least. When two follicles were seen at $17 \mathrm{~mm}$ in diameter on ultrasound, Final oocyte maturation was triggered in both protocols by injecting human chorionic gonadotropin (hCG, Pregnyl; IBSA, the Netherlands). The oocyte pickup was performed under ultrasound guidance and short-term anesthesia after 34-36 hours following hCG injection.

On the day of ovum pickup, before Follicle aspiration, $2 \mathrm{ml}$ of patients' blood was taken and centrifuged for $10 \mathrm{~min}$ at $3000 \mathrm{~g}$ at $5^{\circ} \mathrm{C}$. Next, the serum was separated and stored at $-80^{\circ} \mathrm{C}$ until CXCL8 protein and mRNA expression were measured using the ELISA and Real-Time PCR, respectively.

Follicular fluid was aspirated separately from each follicle during ultrasound-guided transvaginal retrieval. Next, each follicular fluid that was not clear or was contaminated with blood was excluded from the study. Then, each follicular fluid was collected in sterile tubes separately and was centrifuged for $10 \mathrm{~min}$ at $3000 \mathrm{~g}$ at $5^{\circ} \mathrm{C}$. Finally, the supernatant was kept at $-80^{\circ} \mathrm{C}$ for CXCL8 measurement by ELISA and Real-Time PCR.

The oocyte-cumulus complex was collected immediately from follicular fluid aspiration. The oocyte-cumulus complex was exposed to hyaluronidase enzyme (ART-4007, SAGE In-Vitro Fertilization, Inc.), and then cumulus oophorus and corona radiate were removed from each oocyte mechanically by repeated aspiration into a finely drawn Pasteur pipette. The Cumulus cells of each individual were stored separately in a tube at $-80^{\circ} \mathrm{C}$ to measure the level of protein and mRNA of chemokine CXCL8.

\subsection{Oocytes and embryos assay}

After separating the oocytes from the cumulus cells, the oocytes were evaluated for the signs of meiotic maturation, taking into account the cytoplasm granulation and the presence or absence of the first polar body using a stereomicroscope (Nikon, SMZ 1000) and an inverted microscope (Olympus, IX53). The oocytes were divided into germinal vesicles (GV), metaphase I (MI), and metaphase II (MII). The metaphase II oocytes were considered mature oocytes and were processed by ICSI. Then they were individually placed into droplets of Sage 1Step medium (67020010A, SAGE In-Vitro Fertilization, Inc.), covered with mineral oil (ART4008-5P, SAGE In-Vitro Fertilization, Inc.), and maintained in an incubator at $37^{\circ} \mathrm{C}$ under $5 \% \mathrm{CO} 2$ (Esco MIRIß Multiroom incubator).

Fertilization results were assessed 16-18 h after ICS by identifying two pronuclei, and embryo cleavage was evaluated on days 2 and 3. Every embryo was graded on day 3 based on cell count, regularity of blastomeres, degree of cytoplasm fragmentation, and zona pellucida thickness[25, 26]. Embryos with equal blastomeres and without cytoplasm fragmentation were referred to as A-grade embryos considered good quality embryos. Information for each individual includes the count of oocytes obtained, the count of GV, MI, MII oocytes, oocyte maturity (ratio of the count of metaphase II oocytes to the total oocytes in percentage), the count of embryos obtained, the count of A-grade embryos, and good quality embryos (ratio of the A-grade embryos count to the total embryos in percentage) was recorded in both groups and used for statistical analysis.

\subsection{Evaluation of CXCL8 protein levels by Enzyme-linked immunosorbent assay method (ELISA)}

The protein level of CXCL8 in all samples, serum, follicular fluids, and cumulus cells was measured using ELISA commercial kit (KPG-HIL8, Kerman, Iran) according to the manufacturer's instructions. In this method, plates in which the anti-chemokine IL8 antibody was attached were used. The cumulus cells were first diluted with RIPA buffer to measure chemokine CXCL8 protein. Adding samples to these wells bound the CXCL8 chemokine to the antibodies. Next, these molecules were identified by adding specific antibodies against the biotin-bound CXCL8 
chemokine. By adding HRP-AVIDIN to the vials, due to the strong affinity of AVIDIN for biotin, this compound binds to antibodies, and by adding HRP substrate, TMB, which is a colorless substance, depending on the amount of chemokine CXCL8, it turned blue. Finally, by adding the stopper solution, the reaction stopped, and due to the change in $\mathrm{pH}$, the blue color turned yellow. The generated yellow color was measured in parallel using an ELISA reader (ChemWell Fusion, 4800, USA). The sensitivity of this kit was $2 \mathrm{pg} / \mathrm{ml}$.

\subsection{Purification of mRNA and complementary DNA (cDNA) synthesis}

Extraction of mRNA was performed using a commercial kit (Karmania Pars Gene Company, Kerman, Iran) and based on the company instruction. In brief, the samples were incubated with lysis buffer for $5 \mathrm{~min}$. The participation buffer was added to the Supernatant solution after RNA separating. The complex was added to the high absorbance column, and after centrifuge (12000 $\mathrm{g}$ for 5 minutes), the washing buffer was added. Finally, 30 $\mathrm{mL}$ DNase/RNase free water was added to the column, and after centrifuge, the purified mRNA was collected.

The extracted mRNA was directed to be converted to cDNA using the specific kit (KPG-cDNA, Kerman, Iran) accordingly manufactured kit. The synthesized cDNA was stored at $-80^{\circ} \mathrm{C}$ to perform further investigation.

\subsection{Real-Time PCR assay}

Real-Time PCR for evaluating CXCL8 mRNA levels was performed using a Real-Time PCR system (Rotorgene 6000, Qiagen - Corbett Research) and a commercial kit from ((KPG-RTCXL8, Karmania Pars Gene Company, Iran). The relative quantification was performed by measuring the increase in fluorescence light due to SYBR Green bonding. The quantitative Real-Time PCR reactions were run in $20 \mu \mathrm{l}$, including $5 \mu \mathrm{l}$ of cDNA, $10 \mu \mathrm{l}$ of SYBR Green Master Mix, $10 \mu \mathrm{mol}$ of complementary primer at volumes of $2 \mu \mathrm{l}$, and $3 \mu \mathrm{l}$ of deionized water. Beta-actin housekeeping genes were used to normalize amplification data. The relative expression of mRNA was calculated using the $\Delta \Delta \mathrm{CT}$ method. The raw data were analyzed using the $2^{-\Delta \Delta C t}$ formula[27].

\subsection{Statistical analysis}

Data were analyzed using SPSS version 23. A comparison of the variables between the test and control groups was made using an independent t-test. One-way ANOVA analysis of variance was used to analyze the data among each group's samples (Serum, follicular fluids, and cumulus cells). Pearson's correlation test was used to analyze the correlations between the data in each group. The results are presented as the mean \pm SEM. The $p$ values less than 0.05 were considered significant.

\section{Results}

\subsection{Comparison of Blood biochemical different parameters in the women undergoing ICSI in the test and control groups}

The women with an average age of 20 to 35 years and BMl<27 kg/m2 were selected. Different parameters were compared in 54 subfertile women with female factor infertility in the test group and 33 fertile women with male factor infertility in the control group undergoing ICSI.

The comparison between ages, Body mass index (BMI), and hormonal tests (Luteinizing Hormone, Follicle Stimulating Hormone, Thyroid-stimulating Hormone, Anti Mullerian Hormone, and Prolactin) of patients indicated 
no significant difference in the test and control groups ( $p>0.05)$ (Table 1).

\subsection{Evaluated of oocytes and embryos in the women undergoing ICSI in the test and control groups}

The count of oocytes obtained, GV, MI, MIl oocytes, and oocyte maturation rate were compared in the test and control groups. The mean count of oocytes obtained and MII oocytes were significantly lower in the test group than the control group ( $p=0.049$ and $p=0.016$, respectively), but there was no difference between the mean values of GV and $\mathrm{MI}$ oocytes in the test and control groups ( $p=0.434$ and $p=0.665$, respectively). The oocyte maturation rate showed a significant decrease in the test group $(p=0.043)$. Evaluation of the embryos was indicated that there was no significant difference in the count of embryos obtained, the count of A-grade embryos, and the percentage of good quality embryos in the test compared the control groups $(p=0.095, p=0.149$, and $p=0.532$, respectively) (Table 2).

\subsection{Evaluated of CXCL8 protein in the women undergoing ICSI in the test and control groups}

Comparison between the amount of chemokine CXCL8 protein in the serum, follicular fluid, and cumulus cells was indicated a significantly higher mean concentration of protein of CXCL8 in three media in the test group compared to the control group (serum: 1.35 times, $p=0.008, F F: 2.11$ times, $p=0.000$, and CCs: 1.41 timed, $p=0.035)($ Fig. 1 ).

The level of CXCL8 protein was compared in pairs between the serum, follicular fluid, and cumulus cells in the test and control groups. There was a significant difference in levels of CXCL8 protein in the follicular fluid and cumulus cells than serum in the test and control groups $(p<0.05)$. The amount of CXCL8 protein indicated a significant increase in the follicular fluid than cumulus cells in the test group $(p=0.000)$, but there was no significant difference in the control group $(p=0.824)$ (Fig. 1).

\subsection{Evaluated of CXCL8 mRNA expression in the women undergoing ICSI in the test and control groups}

The CXCL8 mRNA expression was examined in the serum, follicular fluid, and cumulus cells in the test and control groups. The results were indicated a significantly higher mRNA expression of CXCL8 in three media in the test group compared to the control group (serum: 1.46 times, $p=0.044$, FF:6.60 times, $p=0.000$, and CCs: 5.43 timed, $\mathrm{p}=0.003$ ) (Fig. 2).

Comparison between the serum, follicular fluid, and cumulus cells in pairs in the test and control groups indicated no significant difference in CXCL8 mRNA expression in the control group ( $p>0.05)$. The CXCL8 mRNA level was significantly less in serum than the follicular fluid and cumulus cells $(p=0.000$, and $p=0.005$, respectively), but there was no significance between follicular fluid and cumulus cells in the test group ( $p=0.609$ ) (Fig. 2).

\subsection{Relationship CXCL8 gene expression with oocyte maturity and Embryo in the test and control groups}

Pearson's correlation test was used to examine the relationship between the expression of CXCL8 protein and mRNA with oocyte maturity and embryo quality. The results indicated that the rates of expression of chemokine CXCL8 in the serum, follicular fluid, and cumulus cells in the test group were inversely related to the oocyte maturity $(p<0.05)$. There was no significant relationship between the rates of CXCL8 expression and embryo quality in any of the serum, follicular fluid, and cumulus cells media in the test group ( $p>0.05)$ (Table 3).

\section{Discussion}


The present study examined the expression of the chemokine CXCL8 gene specifically in serum, follicular fluid, and cumulus cells to evaluate the possible role of CXCL8 chemokine as a biomarker for oocyte maturation and embryo quality in women undergoing ICSI.

Chemokines are produced by different cells such as epithelial cells, fibroblasts, endothelial cells, macrophages, lymphocytes, and mast cells in response to inflammatory stimulations in the immune system[28]. They are responsible for the uptake of leukocytes and play an important role in inflammatory processes of the ovary in both physiological and pathological conditions[29]. Chemokine CXCL8 is the most well-known chemokine, with the most studies on the reproductive system[30]. It was detected as a proinflammatory cytokine in the uptake and activation of the neutrophils in the human preovulatory follicle[9, 31], and ART cycles results[30, 32, 33].

The study on the expression of chemokine CXCL8 protein and mRNA and comparison of the test and control groups indicated that this chemokine expression was significantly higher in the serum, follicular fluid, and cumulus cells of subfertile women with female factor infertility than male factor infertility. The results were consistent with a study by Singh and colleagues (2016), who found that the levels of chemokine CXCL8 protein were higher in women with endometriosis than in the control group[34]. Also, a study by Ito and colleagues (2000) reported that serum and ascites fluid of patients with ovarian hyperstimulation syndrome contained high concentrations of CXCL8[35]. The reason for these results is probably due to a greater activity of immune system cells and leukocytes activity, and thus greater inflammation of the ovaries in subfertile women with female infertility causes[15, 28, 32].

Comparing the chemokine CXCL8 protein and mRNA level between the serum and follicular fluid indicated a significant difference in the level of CXCL8 protein by 2.9 times and in the level of CXCL8 mRNA by 4.5 times in the follicular fluid than the serum in the test group, while a significant increase was seen just in the amount of CXCL8 protein in the follicular fluid in the control group. The high levels of CXCL8 protein in the follicular fluid in the control group were consistent with the results of a study by Arici and colleagues (1996) found that chemokine CXCL8 protein increased in the follicular fluid before ovulation[13]. The other study also confirmed Malizia and colleagues' results (2010), who found that IL-8 was higher in the ovarian follicular fluid in both groups of patients with normal cycle and IVF cycle[12]. The cause of the increased level of CXCL8 expression in the follicular fluid compared to the serum in the female factor infertility group can be attributed to the expression and secretion of CXCL8 from ovarian cells, including macrophages and monocytes, cumulus cells around the oocyte, and granulosa cells, which apart from blood immune cells, can express this chemokine separately and secrete it into the follicular fluid[13, 14, 36, 37]. According to Fujii and colleagues' study (2003), different types of ovarian cells, including granulosa cells, theca cells, and stromal cells, are the sources of mRNA of CXCL8 chemokine[38].

CXCL8 protein and mRNA levels were compared in cumulus cells and serum. A significant increase of CXCL8 protein and mRNA were seen by 1.89 times in the level of CXCL8 protein and 3.7 times in the level of CXCL8 mRNA in the cumulus cell than serum in the test group, but it was significant only in the amount of CXCL8 protein by 1.8 times in the control group. These results indicated that CXCL8 protein could be produced independently in the cumulus cells in both women groups with female factor and male factor infertility and be secreted into the follicular fluid. However, the CXCL8 gene could be expressed to a greater extent in women with female factor infertility.

Comparison between the follicular fluid and cumulus cells indicated a significant increase in the level of CXCL8 protein in the follicular fluid than cumulus cells in the test group, but there was no significance in CXCL8 mRNA. A 
possible cause for a higher level of CXCL8 protein in the follicular fluid in women with female factor infertility was found in a study by Szukiewicz and colleagues (2007); they indicated that IL-8 is stored in mast cells of the ovary and is released at the early stages of inflammation. The IL-8 causes more leukocytes to be absorbed into the theca layer of the follicle, so that they increase vascular permeability, more migration of leukocytes, macrophages, and mast cells to the ovary[39]. It causes more chemokine production in the follicular fluid. It is also possible that more CXCL8 chemokine-producing cells such as neutrophils and macrophages will increase in the ovary in the test group.

Previous studies were indicated that follicular fluid, as an oocyte microenvironment, is biological fluid rich in cytokines and chemokines that affects oocytes in the form of autocrine and paracrine[16, 21, 23]. The oocyte and follicle maturation events occur within the follicular fluid, so follicular fluid provides a unique window into the oocyte maturation $[40,41]$. This study assessed the impact and relationship between chemokine CXCL8 gene expression on oocyte maturity and embryo quality.

In this study, the mean count of oocytes obtained and MII oocytes were significantly lower in the test group than in the control group. In opposite with us, Alhilali and colleagues (2019) indicated that CXCL8 did not affect the percentage of MII oocytes [42]. The chemokine CXCL8 gene had a significant inverse correlation with oocyte maturation but was not correlated with embryo quality in women with female factor infertility. The results were consistent with Singh and colleagues' study (2016), which found that IL-8 concentration in women with endometriosis was significantly associated with reducing oocyte and embryo quality[34]. Furthermore, Gazvani and colleagues (2000) studied IL-8 concentration in follicular fluid of patients in IVF cycles. They concluded that the presence of IL-8 was an essential part of folliculogenesis, and there was a direct relationship between the concentration of IL-8 and follicle development, but it was not related to the rates of implantation and fertilization [15].

The lack of correlation between the rates of chemokine CXCL8 and embryo quality in this study is inconsistent with a study by Sarapik and colleagues (2012); they found that the rate of CXCL8 was suitable to determine the embryo quality and the results of pregnancy in women with different causes of infertility in the IVF cycle[6]. The results were consistent with Alhilali and colleagues' studies (2019), who did not find any correlation between chemokine CXCL8 and embryo grading in women undergoing ICSI [42]. Liu and colleagues (2020) found no correlation of the rate of CXCL8 with embryo quality in women with primary ovarian insufficiency, too[43].

A negative correlation between the effects of chemokine CXCL8 on oocyte maturation in women with female factor infertility could be explained by the fact that there are more inflammatory cells of the immune system in the blood and ovaries of this group, causing an increase in the expression of CXCL8 by cumulus cells around the oocyte, macrophages cells, and ovarian monocytes to serum, follicular fluid. The excessive secretion of this chemokine probably causes ultimately negatively affect ovulation and may prevent oocyte maturation.

\section{Conclusions}

These results were indicated that CXCL8 gene expression is higher in subfertile women with female factor infertility, and the amount of CXCL8 protein and mRNA expression correlate with oocyte maturation. It is possible to predict the oocyte quality by measuring the expression of chemokine CXCL8 in the serum or follicular fluid on the oocyte pickup day to achieve the desired result in subfertile women undergoing ICSI. It is also suggested to 
investigate the use of CXCL8 inhibitors or antagonists in the ART cycle; They have been tested to treat several acute and chronic inflammatory diseases to suppress neutrophil activity in humans[44, 45].

\section{Declarations}

\section{Acknowledgements}

The authors like to thank the Academic Center for Education, Culture and Research (ACECR), Infertility Center, Arak, Iran.

\section{Conflict of interest}

The authors report no conflicts of interest.

\section{Authors' contribution}

PK and MJ designed the research. PK and MJ conducted the studies. FT and SZB analyzed the data. PK and MJ interpreted the results. PK and MJ wrote the manuscript. All authors read and approved the manuscript.

\section{Ethical approval}

The Ethics Committee of the Islamic Azad University- Parand Branch approved and oversaw this study (IR.IAU.VARAMIN.REC.1399.035). The patients were informed consent.

\section{Informed consent}

All authors consent to publication of this study.

\section{References}

1. Reimand K, Talja I, Metsküla K, Kadastik Ü, Matt K, Uibo R (2001) Autoantibody studies of female patients with reproductive failure. Journal of Reproductive Immunology 51 (2):167-176

2. Brazdova A, Senechal H, Peltre G, Poncet $P$ (2016) Immune aspects of female infertility. International journal of fertility \& sterility $10(1): 1$

3. Simón C, Caballero-Campo P, García-Velasco JA, Pellicer A (1998) Potential implications of chemokines in reproductive function: an attractive idea. Journal of reproductive immunology 38 (2):169-193

4. Milliken D, Scotton C, Raju S, Balkwill F, Wilson J (2002) Analysis of chemokines and chemokine receptor expression in ovarian cancer ascites. Clinical cancer research 8 (4):1108-1114

5. Jones RL, Hannan NJ, Kaitu'u TuJ, Zhang J, Salamonsen LA (2004) Identification of chemokines important for leukocyte recruitment to the human endometrium at the times of embryo implantation and menstruation. The Journal of Clinical Endocrinology \& Metabolism 89 (12):6155-6167

6. Sarapik A, Velthut A, Haller-Kikkatalo K, Faure GC, Béné M-C, de Carvalho Bittencourt M, Massin F, Uibo R, Salumets A (2012) Follicular proinflammatory cytokines and chemokines as markers of IVF success. Clinical and Developmental Immunology 2012

7. Büscher U, Chen F, Kentenich H, Schmiady H (1999) Cytokines in the follicular fluid of stimulated and nonstimulated human ovaries; is ovulation a suppressed inflammatory reaction? Human reproduction 14 (1):162- 
166

8. Caballero-Campo P, Domínguez F, Coloma J, Meseguer M, Remohí J, Pellicer A, Simón C (2002) Hormonal and embryonic regulation of chemokines IL-8, MCP-1 and RANTES in the human endometrium during the window of implantation. Molecular human reproduction 8 (4):375-384

9. Runesson E, Boström E-K, Janson PO, Brännström M (1996) Endocrinology and paracrinology: the human preovulatory follicle is a source of the chemotactic cytokine interleukin-8. MHR: Basic science of reproductive medicine 2 (4):245-250

10. Runesson E, Ivarsson K, Olof Janson P, Brännström M (2000) Gonadotropin-and cytokine-regulated expression of the chemokine interleukin 8 in the human preovulatory follicle of the menstrual cycle. The Journal of Clinical Endocrinology \& Metabolism 85 (11):4387-4395

11. Bukulmez O, Arici A (2000) Leukocytes in ovarian function. Human reproduction update 6 (1):1-15

12. Malizia BA, Wook YS, Penzias AS, Usheva A (2010) The human ovarian follicular fluid level of interleukin-8 is associated with follicular size and patient age. Fertility and sterility 93 (2):537-543

13. Arici A, Oral E, Bukulmez O, Buradagunta S, Engin O, Olive DL (1996) Interleukin-8 expression and modulation in human preovulatory follicles and ovarian cells. Endocrinology 137 (9):3762-3769

14. Belayet HM, Kanayama N, Khatun S, Asahina T, Okada Y, Kitamura K, Kobayashi T, Terao T (2000) Pharmacologic doses of interleukin 8 suppositories induce follicular maturation in rabbits. Cytokine 12 (4):361-367

15. Gazvani MR, Bates M, Vince G, Christmas S, Lewis-Jones DI, Kingsland C (2000) Follicular fluid concentrations of interleukin-12 and interleukin-8 in IVF cycles. Fertility and sterility 74 (5):953-958

16. Mendoza C, Ruiz-Requena E, Ortega E, Cremades N, Martinez F, Bernabeu R, Greco E, Tesarik J (2002) Follicular fluid markers of oocyte developmental potential. Human Reproduction 17 (4):1017-1022

17. Huang G, Zhou C, Wei C-j, Zhao S, Sun F, Zhou H, Xu W, Liu J, Yang C, Wu L (2017) Evaluation of in vitro fertilization outcomes using interleukin-8 in culture medium of human preimplantation embryos. Fertility and sterility 107 (3):649-656

18. Combelles CM, Racowsky C Assessment and optimization of oocyte quality during assisted reproductive technology treatment. In: Seminars in reproductive medicine, 2005. vol 03. Copyright@ 2005 by Thieme Medical Publishers, Inc., 333 Seventh Avenue, New ..., pp 277-284

19. Ostanin A, Aizikovich B, Aizikovich I, Kozhin AY, Chernykh E (2007) Role of cytokines in the regulation of reproductive function. Bulletin of experimental biology and medicine 143 (1):75-79

20. Ilkhanizadeh B, NAHALI MA, Hajishafiha M, MEHRZAD SM, Nanbakhsh F, Deldar Y, Asadi N, Kiarang N, Saidi V (2013) CORRELATION BETWEEN EMBRYO IMPLANTION AND FOLLICULAR FLUID SELECTED CYTOKINES AND HORMONE LEVELS IN WOMEN UNDER TREATMENT BY MICROINJECTION TECHNIQUE.

21. Dumesic DA, Meldrum DR, Katz-Jaffe MG, Krisher RL, Schoolcraft WB (2015) Oocyte environment: follicular fluid and cumulus cells are critical for oocyte health. Fertility and sterility 103 (2):303-316

22. Richards JS, Pangas SA (2010) New insights into ovarian function. Fertility Control:3-27

23. Spanou S, Kalogiannis D, Zapanti E, Gazouli M, Sfontouris I, Siristatidis C, Mastorakos G (2018) Interleukin 15 concentrations in follicular fluid and their effect on oocyte maturation in subfertile women undergoing intracytoplasmic sperm injection. Journal of assisted reproduction and genetics 35 (6):1019-1025

24. Organisation WH (1999) WHO laboratory manual for the examination of human semen and sperm-cervical mucus interaction. Cambridge university press, 
25. Balaban B, Brison D, Calderon G, Catt J, Conaghan J, Cowan L, Ebner T, Gardner D, Hardarson T, Lundin K (2011) Alpha scientists in reproductive medicine and ESHRE special interest group of embryology. The Istanbul consensus workshop on embryo assessment: proceedings of an expert meeting. Hum Reprod 26 (6):1270-1283

26. Veeck LL (1999) An atlas of human gametes and conceptuses: an illustrated reference for assisted reproductive technology. Taylor \& Francis,

27. Mazandaran AA, Khodarahmi P (2021) The protective role of Coenzyme Q10 in metallothionein-3 expression in liver and kidney upon rats' exposure to lead acetate. Molecular Biology Reports 48 (4):3107-3115

28. Rainczuk A, Rao J, Gathercole J, Stephens AN (2012) The emerging role of CXC chemokines in epithelial ovarian cancer. Reproduction 144 (3):303

29. Field SL, Dasgupta T, Cummings M, Orsi NM (2014) Cytokines in ovarian folliculogenesis, oocyte maturation and luteinisation. Molecular reproduction and Development 81 (4):284-314

30. Borrelli G, Abrao M, Mechsner S (2014) Can chemokines be used as biomarkers for endometriosis? A systematic review. Human Reproduction 29 (2):253-266

31. Belperio JA, Keane MP, Arenberg DA, Addison CL, Ehlert JE, Burdick MD, Strieter RM (2000) CXC chemokines in angiogenesis. Journal of leukocyte biology 68 (1):1-8

32. Vujisic S, Zidovec S (2005) Follicular immunology environment and the influence on in vitro fertilization outcome. Current Women's Health Reviews 1 (1):49-60

33. Adamczak R, Ukleja-Sokołowska N, Lis K, Dubiel M (2021) Function of Follicular Cytokines: Roles Played during Maturation, Development and Implantation of Embryo. Medicina 57 (11):1251

34. Singh AK, Dutta M, Chattopadhyay R, Chakravarty B, Chaudhury K (2016) Intrafollicular interleukin-8, interleukin-12, and adrenomedullin are the promising prognostic markers of oocyte and embryo quality in women with endometriosis. Journal of assisted reproduction and genetics 33 (10):1363-1372

35. Ito M, Harada T, Iwabe T, Tanikawa M, Terakawa N (2000) Cytokine levels in a patient with severe ovarian hyperstimulation syndrome before and after the ultrafiltration and reinfusion of ascitic fluid. Journal of assisted reproduction and genetics 17 (2):118-120

36. Koch AE, Polverini PJ, Kunkel SL, Harlow LA, DiPietro LA, Elner VM, Elner SG, Strieter RM (1992) Interleukin-8 as a macrophage-derived mediator of angiogenesis. Science 258 (5089):1798-1801

37. Chang RJ, Gougeon A, Erickson GF (1998) Evidence for a neutrophil-interleukin-8 system in human folliculogenesis. American journal of obstetrics and gynecology 178 (4):650-657

38. Fujii A, Harada T, Yamauchi N, Iwabe T, Nishi Y, Yanase T, Nawata H, Terakawa N (2003) Interleukin-8 gene and protein expression are up-regulated by interleukin-1 $\beta$ in normal human ovarian cells and a granulosa tumor cell line. Fertility and sterility 79 (1):151-157

39. Szukiewicz D, Pyzlak M, Klimkiewicz J, Szewczyk G, Maslinska D (2007) Mast cell-derived interleukin-8 may be involved in the ovarian mechanisms of follicle growth and ovulation. Inflammation Research 56 (1):S35S36

40. Zamah AM, Hassis ME, Albertolle ME, Williams KE (2015) Proteomic analysis of human follicular fluid from fertile women. Clinical proteomics 12 (1):1-12

41. Hashish N, Badway H, Abdelmoty H, Mowafy A, Youssef M (2014) Does flushing the endometrial cavity with follicular fluid after oocyte retrieval affect pregnancy rates in subfertile women undergoing intracytoplasmic 
sperm injection? A randomized controlled trial. European Journal of Obstetrics \& Gynecology and Reproductive Biology 176:153-157

42. Alhilali MJS, Parham A, Attaranzadeh A, Amirian M, Azizzadeh M (2019) IL-5 in follicular fluid as a negative predictor of the intracytoplasmic sperm injection outcome. Cytokine 113:265-271

43. Liu P, Zhang X, Hu J, Cui L, Zhao S, Jiao X, Qin Y (2020) Dysregulated cytokine profile associated with biochemical premature ovarian insufficiency. American Journal of Reproductive Immunology 84 (4):e13292

44. Russo RC, Garcia CC, Teixeira MM, Amaral FA (2014) The CXCL8/IL-8 chemokine family and its receptors in inflammatory diseases. Expert review of clinical immunology 10 (5):593-619

45. Ness RB, Modugno F (2006) Endometriosis as a model for inflammation-hormone interactions in ovarian and breast cancers. European Journal of Cancer 42 (6):691-703

\section{Tables}

Table1: Comparison of different parameters in the women undergoing ICSI in the test and control groups.

\begin{tabular}{|c|c|c|}
\hline Parameters & $\begin{array}{l}\text { Control group } \\
\mathrm{n}=33\end{array}$ & $\begin{array}{l}\text { Test group } \\
\mathrm{n}=54\end{array}$ \\
\hline Age (years) & $29.70 \pm 0.76$ & $31.20 \pm 0.55$ \\
\hline BMI (kg/m2) & $21.90 \pm 3.27$ & $22.68 \pm 3.67$ \\
\hline Duration of infertility (years) & $4.64 \pm 2.98$ & $5.65 \pm 1.28$ \\
\hline FSH (IU/L) & $6.36 \pm 0.98$ & $6.51 \pm 0.65$ \\
\hline LH (IU/L) & $5.20 \pm 0.98$ & $5.41 \pm 1.02$ \\
\hline $\mathrm{TSH}(\mathrm{m} \mathrm{IU} / \mathrm{L})$ & $2.45 \pm 0.9$ & $2.26 \pm 0.6$ \\
\hline PRL (ng/ml) & $9.89 \pm 0.83$ & $10.31 \pm 1.05$ \\
\hline $\mathrm{AMH}$ & $3.03 \pm 0.39$ & $2.98 \pm 0.46$ \\
\hline \multicolumn{3}{|c|}{$\begin{array}{l}\text { Different parameters were compared in the test group and the control group undergoing ICSI. There were no } \\
\text { significant differences versus the control group based on the T-test. Body mass index (BMI), Follicle } \\
\text { Stimulating Hormone (FSH), Luteinizing Hormone (LH), Thyroid-stimulating Hormone (TSH), Prolactin (PRL), } \\
\text { Anti Mullerian Hormone (AMH). The results are presented as the mean } \pm \text { SEM. }\end{array}$} \\
\hline
\end{tabular}

Table 2: Comparison of different parameters in the women undergoing ICSI in the test and control groups. 


\begin{tabular}{|c|c|c|}
\hline Parameters & $\begin{array}{l}\text { Control group } \\
\mathrm{n}=33\end{array}$ & $\begin{array}{l}\text { Test group } \\
\mathrm{n}=54\end{array}$ \\
\hline No. of oocytes retrieved & $12.60 \pm 0.94$ & $9.48 \pm 1.07^{\star}$ \\
\hline No. of GV oocytes & $0.69 \pm 0.16$ & $0.96 \pm 0.24$ \\
\hline No. of Ml oocytes & $0.78 \pm 0.14$ & $0.69 \pm 0.13$ \\
\hline No. of Mll oocytes & $11.03 \pm 0.88$ & $7.70 \pm 0.90 *$ \\
\hline \multicolumn{2}{|l|}{ (No. of MIl oocytes / No. of oocytes total \%) } & $79.81 \pm 3.10^{*}$ \\
\hline No. of embryos & $8.33 \pm 0.72$ & $6.46 \pm 0.75$ \\
\hline No. of A-grade Embryos & $6.12 \pm 0.63$ & $4.86 \pm 0.56$ \\
\hline \multicolumn{2}{|l|}{ (No. of A-grade Embryos / No. of embryos total\%) } & $78.49 \pm 3.62$ \\
\hline $\begin{array}{l}\text { The mean count of oocytes obtained, MII oocytes a } \\
\text { versus the control group based on the T-test, }(* \mathrm{p}<0 \text {. } \\
\text { Metaphase II oocytes (MII). The results are present }\end{array}$ & $\begin{array}{l}\text { tion rate were si } \\
\text { cle oocyte }(\mathrm{GV}) \text {, } \\
\text { SEM. }\end{array}$ & $\begin{array}{l}\text { Int differences } \\
\text { hase I oocyte (MI) }\end{array}$ \\
\hline
\end{tabular}

Table 3: Correlation of CXCL8 protein and mRNA expression with oocyte maturation (\%) and embryo quality (\%) in three environments: serum, $\mathrm{FF}$, and CCs in the control and test groups. 


\begin{tabular}{|c|c|c|c|c|c|c|c|c|}
\hline & & & Serum & & FF & & CCs & \\
\hline & & & $\begin{array}{l}\text { Oocyte } \\
\text { maturation\% }\end{array}$ & $\begin{array}{l}\text { Embryo } \\
\text { quality\% }\end{array}$ & $\begin{array}{l}\text { Oocyte } \\
\text { maturation\% }\end{array}$ & $\begin{array}{l}\text { Embryo } \\
\text { quality\% }\end{array}$ & $\begin{array}{l}\text { Oocyte } \\
\text { maturation\% }\end{array}$ & $\begin{array}{l}\text { Embryo } \\
\text { quality\% }\end{array}$ \\
\hline \multirow{4}{*}{$\begin{array}{l}\text { CXCL8 } \\
\text { Protein } \\
(\mathrm{pg} \\
/ \mathrm{ml})\end{array}$} & \multirow{2}{*}{$\begin{array}{l}\text { Control } \\
\text { group }\end{array}$} & $r$ & -0.076 & 0.171 & 0.081 & 0.340 & 0.121 & 0.014 \\
\hline & & $\begin{array}{l}P \\
\text { value }\end{array}$ & 0.675 & 0.343 & 0.652 & 0.053 & 0.502 & 0.938 \\
\hline & \multirow{2}{*}{$\begin{array}{l}\text { Test } \\
\text { group }\end{array}$} & $r$ & -0.933 & 0.215 & -0.820 & 0.233 & -0.956 & 0.213 \\
\hline & & $\begin{array}{l}P \\
\text { value }\end{array}$ & $0.000^{\star \star \star}$ & 0.134 & $0.000^{\star \star \star}$ & 0.103 & 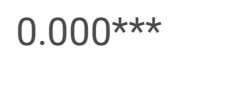 & 0.137 \\
\hline & \multirow{2}{*}{$\begin{array}{l}\text { Control } \\
\text { group }\end{array}$} & $r$ & -0.092 & -0.010 & 0.108 & 0.069 & 0.376 & 0.186 \\
\hline & & $\begin{array}{l}P \\
\text { value }\end{array}$ & 0.612 & 0.956 & 0.549 & 0.702 & 0.058 & 0.299 \\
\hline \multirow{2}{*}{$\begin{array}{l}\text { CXCL8 } \\
\text { mRNA }\end{array}$} & \multirow{2}{*}{$\begin{array}{l}\text { Test } \\
\text { group }\end{array}$} & $r$ & -0.931 & 0.191 & -0.955 & 0.199 & -0.920 & 0.078 \\
\hline & & $\begin{array}{l}P \\
\text { value }\end{array}$ & $0.000 * \star \star$ & 0.184 & $0.000 * \star *$ & 0.166 & $0.000 * \star \star$ & 0.591 \\
\hline $\begin{array}{l}\text { The am } \\
\text { FF, CCs } \\
\text { are pres }\end{array}$ & $\begin{array}{l}t \text { of } \mathrm{C} \text {. } \\
\text { he test } \\
\text { ed as } \mathrm{t}\end{array}$ & 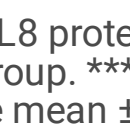 & $\begin{array}{l}1 \text { and } \mathrm{mRNA} \\
<0.001 \text { were } \\
\text { SEM. FF: Foll }\end{array}$ & $\begin{array}{l}\text { ession n } \\
\text { significa }\end{array}$ & $\begin{array}{l}\text { nversely rela } \\
\text { ifference bas }\end{array}$ & $\begin{array}{l}\text { to the } \\
\text { on Pear }\end{array}$ & $\begin{array}{l}\text { te maturatio } \\
\text { 's correlation }\end{array}$ & $\begin{array}{l}\text { serum, } \\
\text { e results }\end{array}$ \\
\hline
\end{tabular}

\section{Figures}




\section{Serum $\square$ Follicular Fluid $\square$ Cumulus Cells}

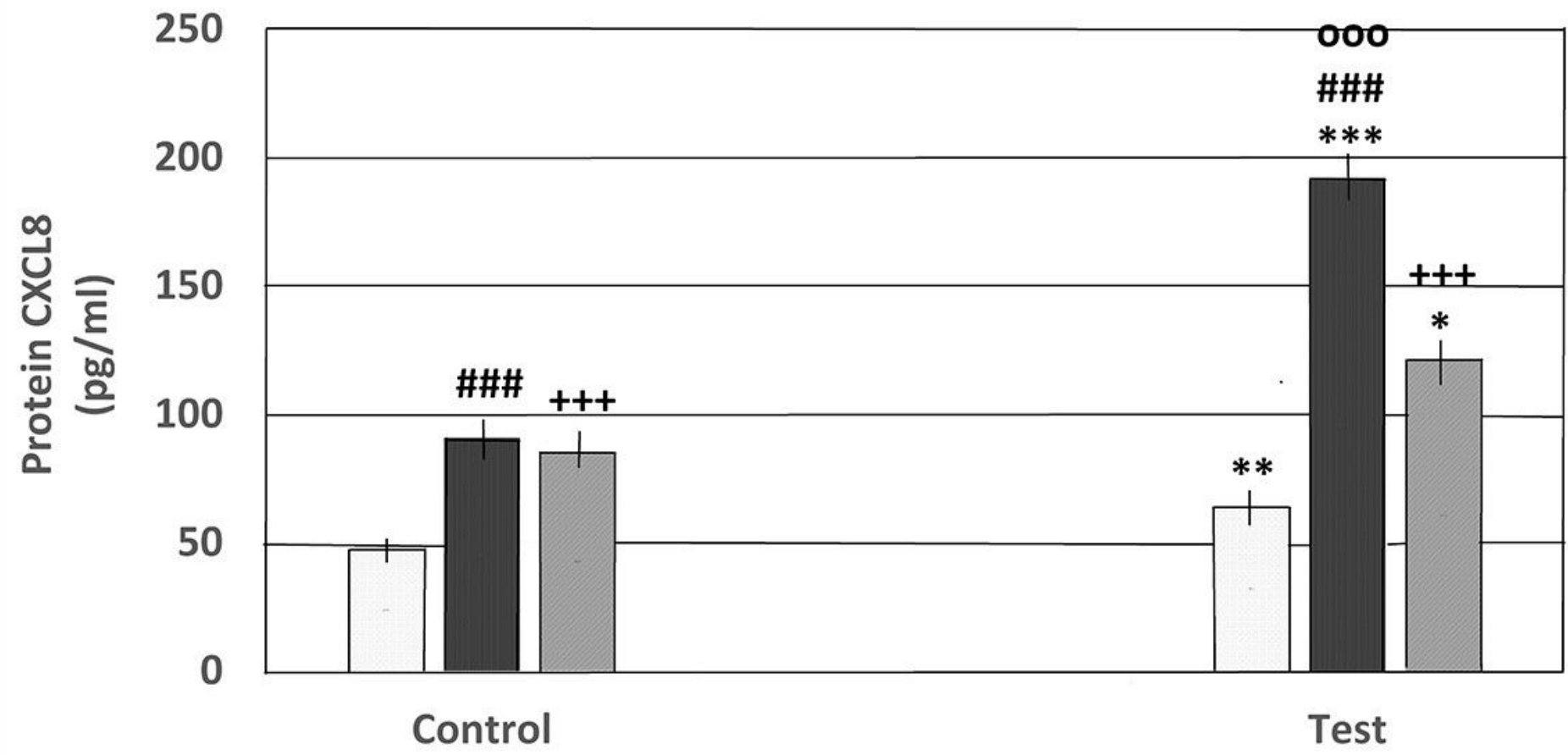

Figure 1

Comparison level of protein of chemokine CXCL8 between the test and control groups in the serum, FF, and CCS samples. The level of protein of chemokine CXCL8 was significantly higher in the serum, FF, and CCs samples in the test group than in the control group based on the t-test, ${ }^{*} p<0.05,{ }^{*} p<0.01,{ }^{* *} p<0.001$. The CXCL8 protein was significantly higher in the follicular fluid than serum in the test and control groups based on the ANOVA test, \#\#\#p<0.001. The CXCL8 protein was significantly higher in the cumulus cells than serum in the test and control groups based on the ANOVA test, $+++p<0.001$. The CXCL8 protein was significantly higher in the follicular fluid than cumulus cells in the test group based on the ANOVA test, ooop<0.001. The results are presented as the mean \pm SEM. FF: Follicular Fluid; CCs: Cumulus Cells. 


\section{Serum $\quad$ Follicular Fluid $\quad$ Cumulus Cells}

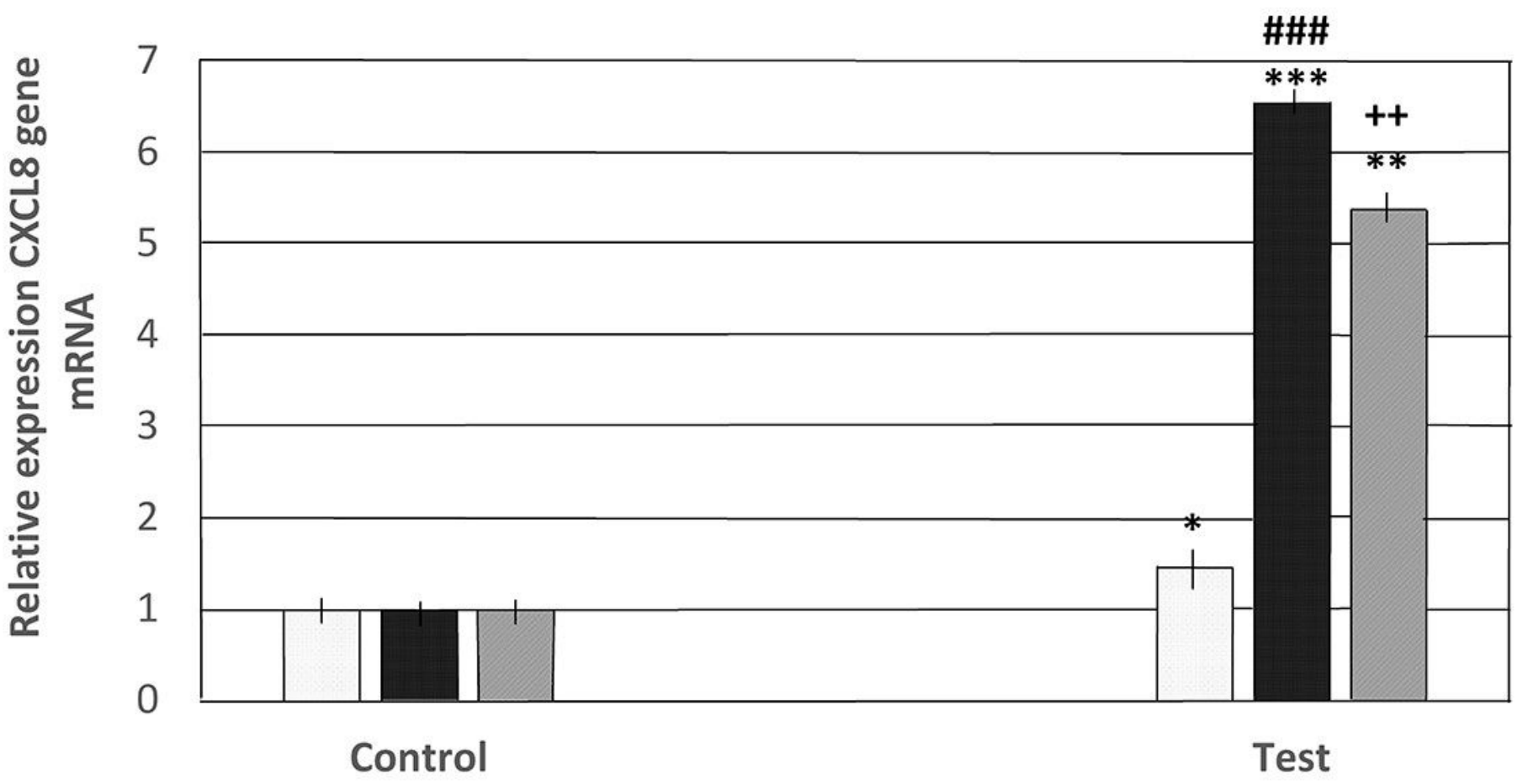

\section{Figure 2}

Comparison of mRNA expression of CXCL8 between the test and control groups in the serum, FF, and CCs samples. The level of CXCL8 mRNA expression was significantly higher in the serum, FF, and CCs samples in the test group than in the control group based on the t-test, ${ }^{*} \mathrm{p}<0.05,{ }^{*} \mathrm{p} \leq 0.01,{ }^{*}{ }^{*} \mathrm{p} \leq 0.001$. The CXCL8 mRNA expression was significantly higher in the follicular fluid than serum in the test group on the ANOVA test, \#\#\#p<0.001. The CXCL8 mRNA expression was significantly higher in the cumulus cells than serum in the test group based on ANOVA test, $++p<0.01$. The CXCL8 mRNA expression was not significantly in the follicular fluid than cumulus cells in the test and control groups based on ANOVA test. The results are presented as the mean \pm SEM. FF: Follicular Fluid; CCs: Cumulus Cells. 